\title{
Understanding the nature and scope of the right to science through the Travaux Préparatoires of the Universal Declaration of Human Rights and the International Covenant on Economic, Social and Cultural Rights
}

\author{
Smith, Tara
}

\section{International Journal of Human Rights}

DOI:

$10.1080 / 13642987.2020 .1715947$

Published: 13/09/2020

Peer reviewed version

Cyswllt i'r cyhoeddiad / Link to publication

Dyfyniad o'r fersiwn a gyhoeddwyd / Citation for published version (APA):

Smith, T. (2020). Understanding the nature and scope of the right to science through the Travaux Préparatoires of the Universal Declaration of Human Rights and the International Covenant on Economic, Social and Cultural Rights. International Journal of Human Rights, 24(8), 1156-1179. https://doi.org/10.1080/13642987.2020.1715947

\footnotetext{
Hawliau Cyffredinol / General rights

Copyright and moral rights for the publications made accessible in the public portal are retained by the authors and/or other copyright owners and it is a condition of accessing publications that users recognise and abide by the legal requirements associated with these rights.

- Users may download and print one copy of any publication from the public portal for the purpose of private study or research.

- You may not further distribute the material or use it for any profit-making activity or commercial gain

- You may freely distribute the URL identifying the publication in the public portal ?
}

If you believe that this document breaches copyright please contact us providing details, and we will remove access to the work immediately and investigate your claim. 


\title{
Article Submission to the International Journal of Human Rights
}

\section{Title Page}

Author: Dr. Tara Smith

Title: Lecturer in International Law and Human Rights

Affiliation: Bangor University, School of Law

Email: t.smith@bangor.ac.uk

Address: Room 010, Athrolys, School of Law, Bangor University, LL57 2DG

Article Title: Understanding the Nature and Scope of the Right to Science through the Travaux Préparatoires of the Universal Declaration of Human Rights and the International Covenant on Economic, Social and Cultural Rights

Word Count: 12, 986 including footnotes.

\begin{abstract}
:
The human right to science is perhaps one of the most relevant rights in modern times, yet it remains one of the least understood human rights to this day. This article examines the drafting history of the right to science to provide fresh insights into the nature and scope of the right in the context of Article 27 of the Universal Declaration of Rights and Article 15 of the International Covenant on Economic, Social and Cultural Rights. The procedural drafting history of the right is analysed to conclude that there was virtually no opposition to the right at any point between 1946 and 1966, but states failed to reach agreement on the precise nature and scope of the right and it is argued that such imprecision has affected the impact of the right in the intervening decades.
\end{abstract}

Keywords: international human rights law; the right to enjoy the benefits of scientific progress; travaux preparatoires; Universal Declaration of Human Rights; International Covenant on Economic, Social and Cultural Rights. 


\section{Understanding the Nature and Scope of the Right to Science through the Travaux \\ Préparatoires of the Universal Declaration of Human Rights and the International \\ Covenant on Economic, Social and Cultural Rights}

\section{Introduction}

The human right to science is perhaps one of the most relevant rights in modern times, yet it remains one of the least understood human rights to this day. ${ }^{1}$ As Schabas astutely observes, where Lauterpacht viewed economic, social and cultural rights as being at the vanishing point of human rights, the right to science ${ }^{2}$ appears to have occupied a place at the vanishing point of economic, social and cultural rights since it was first recognised by innovative drafters more than eight decades ago. ${ }^{3}$ However the place of the right to science in human rights discourse may be about to change, and change rapidly. While the right to science itself has generated very little academic attention to date, ${ }^{4}$ the Committee on Economic, Social and Cultural Rights have indicated an intention to develop a General Comment on the right to science as a matter of priority. ${ }^{5}$ This will hopefully give direction to states and scholars alike in applying and evaluating the right at a time in human history when such direction is needed most. This article examines the drafting history of the right to science to contextualise and inform ongoing interpretations of the right and to support future interpretations of the Committee on Economic, Social and Cultural Right's eventual General Comment on the subject.

The field of international human rights law is dynamic and ever-evolving and the drafting history of a treaty is rarely used deterministically or with the intention of anchoring the meaning of a particular term to a specific point in time. ${ }^{6}$ However the right to science has not been applied authoritatively to date ${ }^{7}$ and as such it remains difficult to define in an objective manner according to either universal or culturally relative understandings. ${ }^{8}$ In such circumstances, the 
drafting history, the travaux préparatoires, of a treaty can be used as a supplementary means of interpretation to either confirm the ordinary meaning of terms or to determine meaning where a plain reading of the text either does not remove ambiguity or results in conclusions that are manifestly absurd or unreasonable. ${ }^{9}$ With little direct interpretation of Article 27 of the Universal Declaration of Human Rights (UDHR) or Articles 15(1)(b), 15(2), 15(3), or 15(4) of the International Covenant on Economic Social and Cultural Rights (ICESCR) to rely upon, ${ }^{10}$ the travaux préparatoires of the two foundational instruments of the right to science can be instrumental in developing common and consistent understanding. ${ }^{11}$

This article firstly outlines the procedural drafting history of the right to science before exploring relevant discussions between drafters on the nature and scope of the right at various points in time between 1946 and 1966. In so doing, this article confirms that while there was little, if any, opposition to including the right to science in either the UDHR or the ICESCR, closely aligning the right to science with cultural rights was never fully justified, and the scope of the right was never clarified prior to the adoption of either instrument. In many ways, the drafting history illustrates well-intentioned attempts to develop an innovative, progressive and necessary human right that could be as relevant in the era of its conception as in the future. Whether the right is capable of delivering on this promise has yet to be seen.

\section{The Procedural Drafting History of the Right to Science}

During the drafting of the UN Charter, efforts had been made to include a bill of rights in the final text, but those efforts did not succeed. Nonetheless there was an appetite amongst states to develop an international bill of rights at the earliest opportunity following the establishment of the UN. ${ }^{12}$ The Commission on Human Rights was given this task, and while finding its feet in early $1947,{ }^{13}$ the Division of Human Rights of the UN Secretariat prepared a preliminary outline of an international bill of rights based on proposals that had been received up to that 
point through the temporarily constituted Nuclear Commission on Human Rights and various other UN channels. ${ }^{14}$ The Drafting Committee, therefore, did not have to start their work in a vacuum or with a blank page. As the right to science had featured in some submissions by states, and as it had appealed to John Humphrey, a former Canadian diplomat and then Director of the Division of Human Rights, the Drafting Committee of the Commission on Human Rights were presented with the right to science for consideration from the very beginning.

The right to science was included in the preliminary draft prepared by John Humphrey as Article 44. This draft article suggested that the Commission on Human Rights consider whether the final international bill of rights should recognise the right of everyone to 'participate in the cultural life of the community, to enjoy the arts and to share in the benefits of science. ${ }^{15}$ The inclusion of the right to science in the UN Secretariat's draft could be viewed as an innovation in human rights at the time - a development borne not of judicial activism but, perhaps, of drafters' enthusiasm - as there were comparatively few legal sources from which a universal right of this kind could be discerned or distilled. ${ }^{16}$ However, in all sources but one relied upon by Humphrey to develop Article 44, science is not mentioned as a stand-alone right, but referred to conjunctively with education, culture, and the arts. ${ }^{17}$ Article 44 of the UN Secretariat's draft appears to reflect this balance.

The only source that regarded the right to science as an independent right was the Draft Declaration of the International Rights and Duties of Man, ${ }^{18}$ submitted to the UN General Assembly in 1946 by Chile ${ }^{19}$ but prepared by the Inter-American Juridical Committee. ${ }^{20}$ The text of Article XV of the Draft Declaration of the International Rights and Duties of Man places significant emphasis not only on the right of individuals to access scientific progress, but also on the intellectual property rights of scientists responsible for such progress. ${ }^{21}$ Moreover it suggests that the state has a duty to protect individuals against the negative uses of scientific progress. ${ }^{22}$ Although neither intellectual property rights nor the purpose of science were 
reflected in the UN Secretariat's initial draft, these ideas featured prominently in subsequent drafting debates. This source of the right to science was therefore extremely influential on the ultimate development of the right in both the UDHR and ICESCR, and it is worth examining further.

The Inter-American Juridical Committee broadly attributed their inclusion of non-traditional rights - such as the right to science - in the Draft Declaration of the International Rights and Duties of Man to theories of distributive justice that required the state to play a new, more active role in supporting individual development. ${ }^{23}$ The Inter-American Juridical Committee felt that realising fundamental human rights had grown to require more of the state than mere restraint. To them, states needed to cooperate actively with fundamental rights, and this cooperation would 'obviously depend not merely upon the extent of [the state's] material resources but upon its ability to organize its resources and to distribute its aid effectively among its people in accordance with the degree of their need. ${ }^{24}$ The Inter-American Juridical Committee felt that the 'growth of civilisation'25 and accompanying new 'ideals of social justice', ${ }^{26}$ required the list of existing human rights to be developed and expanded. The right to science was therefore included in the Draft Declaration of the International Rights and Duties of Man. But given the ideologically embryonic state of the right at this time, it is perhaps surprising that it made its way into the very first draft of what would ultimately become the UDHR and subsequently the ICESCR.

In authoring the draft outline of an international bill of rights which the UN Secretariat provided to the Commission on Human Rights, John Humphrey had relative freedom to develop a draft which included whatever human rights he saw fit. With the intention to combine 'humanitarian liberalism with social democracy ${ }^{27}$ in developing the draft, Humphrey may have seen more relevance in the right to science than others would have at that juncture, although it should be noted that the UN Assistant-Secretary-General for Social Affairs at the time, Henri Laugier, 
also held strong views regarding the impact of scientific progress on fundamental freedoms. ${ }^{28}$ It could be surmised that at the time, recognising a universal right to science had perhaps more to do with the personalities involved in the very initial stages of the drafting of the UDHR than any substantive weight that could be attributed to the fundamental and autonomous nature of right itself. ${ }^{29}$ Nonetheless, Humphrey appears to have taken care to ensure that Article 44 of the UN Secretariat's draft reflected the right to science as conveyed in the preponderance of sources received at that point, not just the contours of the Draft Declaration of the International Rights and Duties of Man. ${ }^{30}$ Had Humphrey not included the right to science in the initial draft outline, it may not have been introduced through subsequent discussions and deliberations in the Commission on Human Rights. ${ }^{31}$ Once in the draft, though, it became difficult to object to or remove. ${ }^{32}$ Much of the credit for the existence of the right to science in human rights instruments today should therefore be attributed to John Humphrey and his decision to include it in the preliminary draft sent by the UN Secretariat to the Commission on Human Rights.

In June 1947, the Drafting Committee established by the Commission on Human Rights began to consider the option of developing two human rights instruments rather than one: the first, a non-binding declaration or manifesto containing general principles, and the second, a convention containing legally binding obligations. ${ }^{33}$ The Drafting Committee convened a temporary Working Group to divide the initial draft prepared by Humphrey along these bifurcated lines. Rene Cassin, the French Delegate, was given the task of developing the first draft of the non-binding declaration, and Geoffrey Wilson and Charles Malik, representatives of the United Kingdom and Lebanon respectively, were given the task of developing the first draft of the legally binding convention. ${ }^{34}$ The right to science was included by Cassin in the draft declaration, but it was not included by Wilson and Malik in the draft convention. ${ }^{35}$ This demonstrates that states were reluctant, even at these early stages, to equate the right to science with what they considered to be more fundamental and established human rights. 
In Cassin's draft non-binding declaration - the seed from which the UDHR grew - the article on the right to science was almost identical to the version that the UN Secretariat had prepared, and after the Drafting Committee considered it, the right remained largely unchanged in the draft that was sent to the Commission on Human Rights for further development. ${ }^{36}$ However, at this time, Cassin also introduced a new article referring to the intellectual property rights of authors of scientific works ${ }^{37}$ which echoed some parts of Article XV of the Draft Declaration of the International Rights and Duties of Man that John Humphrey had not included in the UN Secretariat's draft. The inclusion of intellectual property rights proved to be extremely controversial throughout the drafting of the UDHR, and it was inserted and removed from the draft text several times before ultimately being included in the final text of the UDHR and subsequently the ICESCR. ${ }^{38}$

Following the adoption of the Universal Declaration of Human Rights on $10^{\text {th }}$ December 1948 , in which the right to science was included under Article 27, efforts turned immediately towards drafting a legally binding convention to give force to the rights in the non-binding declaration. Initial drafts of the convention focused almost exclusively on civil and political rights, as Wilson and Malik had done years earlier, and the right to science was excluded from early discussions. However, in December 1950 the UN General Assembly insisted that the 'interconnected and interdependent ${ }^{39}$ nature of civil, political, economic, social and cultural rights required that all such rights be expressed as legally binding provisions in the draft covenant $^{40}$ and so the right to science was brought back into the picture. ${ }^{41}$ The right to science as discussed by the Commission on Human Rights in their seventh session in $1951,{ }^{42}$ was subsequently highlighted as a positive early example of how rights in the covenant should go beyond the parameters of the UDHR by not only establishing the right, but also by establishing the responsibilities of states in relation to each right. ${ }^{43}$ 
Nonetheless, the UN General Assembly insisted in February 1952 that more precision was needed. It requested the Commission on Human Rights to revise the draft articles on economic, social and cultural rights in light of state submissions received and discussions held at the UN General Assembly ${ }^{44}$ with a view to developing not one but two separate conventions that would give effect to the rights in the UDHR: one containing civil and political rights, and the other, economic, social and cultural rights. ${ }^{45}$ During its eighth session in 1952 , the Commission on Human Rights began this work. The right to science became draft Article 16 of a stand-alone covenant on economic, social and cultural rights ${ }^{46}$ and upon the conclusion of the Commission on Human Right's work, it was referred by ECOSOC to the UN General Assembly in July 1954. ${ }^{47}$ The UN General Assembly passed the draft covenants to the Third Committee ${ }^{48}$ for further consideration. The right to science wasn't examined by the Third Committee until 1957. However, the right as finalised by the Third Committee at this time was ultimately adopted by the UN General Assembly as Article 15 of the International Covenant on Economic, Social and Cultural Rights on 16 December 1966. While inclusion of the right to science in both the UDHR and the ICESCR was uncontroversial at all stages, consensus on the right was evident at a more abstract level; states never truly reached agreement on the precise nature and the scope of the right. In this way, the right to science might be interpreted, as the right to culture has been, ${ }^{49}$ as an 'incompletely theorized agreement'. ${ }^{50}$

\section{The Nature of the Right to Science}

Since its adoption in the UDHR, the right to science has been accepted as a fundamental human right and one which is closely associated with cultural rights. The initial reasons for this were, as discussed above, largely attributable to the way in the rights to art, science and culture were represented in the initial draft of the international bill of rights that John Humphrey prepared on behalf of the UN Secretariat for the Commission on Human Rights. However, during the development of both the UDHR and ICESCR, the nature of the right to science featured in 
discussions amongst states. The extent to which the right to science could be considered a substantive and fundamental human right was explored somewhat by drafters of both the UDHR and ICESCR, though the reason for categorising the right to science as an economic, social and cultural right was never fully clarified or justified.

\section{a. The Right to Science as a Substantive and Fundamental Human Right}

During the first meeting of the Commission on Human Rights' Drafting Committee in 1947, some members felt that the right to science might be more appropriately placed in the preamble of what would eventually become the UDHR. ${ }^{51}$ Such suggestions raised questions over the nature of the right to science as a substantive human right - had John Humphrey read too much into the few state-submitted sources of rights that mentioned the right to science? While the Drafting Committee ultimately included the right to science as a substantive human right in the first draft that it prepared for the Commission on Human Rights, they nonetheless noted concerns that had been raised and suggested to the Commission that they might wish to reconsider the issue and place the right in the preamble instead. ${ }^{52}$ Preambular paragraphs tend to invoke the spirit and purpose of the instrument in question, and so it is interesting to observe that, instead of rejecting the concept entirely at the outset, states, at the very least, felt that accessing scientific progress represented the collective spirit and purpose of other rights being enumerated at that time. On balance, the extent of the evidence available in the late-1940s would suggest that even a preambular reference to science would have represented a significant advancement, and the Drafting Committee would have been perfectly justified in placing it there. Concluding that, despite concerns, the right to science ought to be presented to the Commission on Human Rights as a draft article represented the kind of Promethean ${ }^{53}$ lawmaking that is rarely nowadays witnessed. 
During the third session of the Commission on Human Rights in June 1948, states had become comfortable with the idea of a stand-alone human right to science, and they were keen to endorse it as being a fundamental human right. For example, the delegate from the USSR asserted that ' $[\mathrm{t}]$ he benefits of science were not the property of a chosen few but the heritage of the people'. ${ }^{54}$ During discussions in the Third Committee in late-1948 Rene Cassin, the French delegate, observed that the right to science was intended to give those who had played no part in making scientific progress an indisputable right of access to the benefits of that progress. ${ }^{55}$ States at this juncture, therefore, felt that the right to science contained something separate and additional to other human rights, and as such could be regarded as being more than just a constituent element of all human rights, as would be implied by a reference in the Preamble.

During the drafting of the ICESCR a decade later, it was clear that the value attributed to the right to science had grown significantly. The delegate from the Philippines, Mr Brillantes, affirmed the unequivocal existence of the right to science as a substantive right, and suggesting that it 'dealt with the noblest rights that could be attributed to an individual. ${ }^{56} \mathrm{Mr}$. Havet, the delegate from UNESCO, regarded the right to science as a 'coping-stone of the edifice of human rights' ${ }^{57} \mathrm{He}$ argued that science was important because of the part it played in the development of culture and because of the role it could play in improving human life in general. ${ }^{58}$ To him, the right to science wasn't just a constituent part of other human rights, but 'to a great extent the determining factor for the exercise by mankind as a whole of many other rights. ${ }^{59}$ The status of the right to science as a fundamental and substantive human right had been confirmed at this point and it was abundantly clear that it had become much more than a preambular nicety.

The interconnected nature of the right to science and other human rights was evident throughout the drafting history of the right. For example, the protection of scientists and the 
role of science was discussed in great depth by the Commission on Human Rights outside the parameters of the right to science proper. For example, significant time was spent considering the right of scientists to seek asylum and the rights to freedom of expression and thought as possessed by individual scientists. ${ }^{60}$ As the right to science was included in the UDHR and ICESCR in addition to these considerations, there is an obvious implication that, while being necessary for the realisation of other rights, the right to science is distinct from other rights and as such possesses an autonomous and distinct character.

To this end, there was a clear intention throughout the drafting history of both the UDHR and ICESCR to distinguish equal access to scientific discoveries from other equality issues. During the Commission on Human Rights' eighth session, discussing the draft ICESCR, the Chilean delegate, Mr. Valenzuela, argued that '[i]n many countries, people were prevented from enjoying the benefits of scientific discoveries and inventions because the latter were suppressed by powerful economic or political interests which were unwilling to make the capital investment required; it was necessary to ensure that such benefits were made available to all, without obstruction. ${ }^{61}$ The intention behind the right to science was not just to guarantee equal access to science and scientific opportunities, but to overcome, as Article XV had intended in the Draft Declaration of the International Rights and Duties of Man had attempted, obstinate intellectual property hurdles and the construction of monopolies which could ultimately prevent individuals from sharing in the benefits of science. ${ }^{62}$ The right to science, therefore, as a right independent from others into which it could have been subsumed, clearly added value by creating an exception to intellectual property roadblocks in certain circumstances. Given the intention of the drafters, and the rationale for including the right to science as an autonomous right in both the UDHR and ICESCR, the inclusion of intellectual property rights as a corollary to the final version of the right to science in both instruments is all the more puzzling.

\section{b. Is the Right to Science a Civil, Political, Economic, Social or Cultural Right?}


While the right to science has, from the outset been associated with cultural rights - a view perpetuated in recent times by the former UN Special Rapporteur in the field of cultural rights, Farida Shaheed ${ }^{63}$ - the classification of the right as a cultural right, or even as belonging in the category of economic, social and cultural rights in general, is certainly debatable on the basis of the travaux preparatoires of both the UDHR and ICESCR. Cismas has argued that civil, political, economic, social and cultural rights 'intersect not only at the normative level [...] but also, and more importantly, in practice' ${ }^{64}$ Isolating the right to science and assessing whether it has been categorised correctly as a cultural right could therefore be considered a moot point in practice. However, the Special Rapporteur's view that the right to science and the right to culture ought to be 'read together' ${ }^{65}$ is not supported by the drafting history of either right. The drafters of the UDHR acknowledged the relationship between both rights, but they also made a distinction between the right to science and the right to culture in their discussions. While drafters of the UDHR and ICESCR failed to make that distinction clear in the final rendition of both rights, it is clear from the drafting history that there is as strong a rationale for linking the rights to science and culture, as there is for applying the right to science in conjunction with the rights to health and food, for example. ${ }^{66}$

At the very first meeting of the UN General Assembly in 1946, Panama introduced onto the agenda an item proposing the development of a draft declaration of fundamental human rights and freedoms ${ }^{67}$ and to that end, 18 draft international bills of rights were submitted for consideration as preliminary drafts or with the intention of providing a basis for further discussion. ${ }^{68}$ It was observed that drafts produced during and after World War II reflected more deliberately the status of social security in human rights terms than drafts produced before this time, and sharing in the benefits of science appears to have been subsumed under the general theme of social security in those few drafts that referenced it. ${ }^{69}$ Therefore, when the first draft 
of the right to science was developed by the UN Secretariat, access to science potentially ought to have been recognised as a social right rather than a cultural right. ${ }^{70}$

However, perspectives appear to have evolved or changed quickly, because by the time the Drafting Committee of the Commission on Human Rights considered the right to science, the French delegate, Rene Cassin, affirmed the point of view that John Humphrey had conveyed in the UN Secretariat's draft, that 'cultural life included science'. ${ }^{71}$ This was a sentiment echoed by the Chinese delegate, Mr. Chang who observed that "the word "cultural" could have two meanings; it could refer either to the practice of science and the arts, or the ethnical origin of a community'. ${ }^{72}$ At this point in the early drafting history of the right, the classification of the right to science appears to have been set and there was no further consideration of the right to science being more closely related to social, economic, civil or political rights. The right to science, thereafter, was treated as a cultural right and included in Article 27 of the UDHR as such.

During the drafting of the ICESCR, the UN General Assembly requested states and specialised agencies to submit views on the draft covenants as considered by the Third Committee in 1954 . To this end, Yugoslavia made an observation that re-opened the question of the classification of the right to science. The delegate from Yugoslavia suggested that the right to science could be used as a means to solve economic and social problems. ${ }^{73}$ During the Third Committee's twelfth session, interventions reflected earlier suggestions that the right to science might be more of a social right than a cultural right. For example, the Indian delegate, Mr. D’Souza, argued that the right to culture and the right to enjoy the benefits of scientific progress were two entirely different and distinct rights. ${ }^{74} \mathrm{He}$ felt that the right to science addressed something far more practical than the right to culture, which could be quite abstract in its interpretation. 
To the Indian delegate, 'scientific discoveries should benefit not only all individuals but also nations, regardless of their degree of development'. ${ }^{75}$ While the classification of the right to science as a cultural right did not change, the observations are certainly compelling, particularly given the intrinsic role that science now plays in contemporary life.

The drafting history of the right to science demonstrates that there were certainly challenges to the classification of the right to science as a cultural right. Rarely were those challenges countered by compelling arguments in favour of retaining the cultural status of the right to science. Beyond a few scattered opinions at various points in time, no substantive discussion was held to confirm the nature of the right to science as a cultural right at any stage. That the right to science has become so indelibly attached to the right to culture in both the UDHR and the ICESCR is unfortunate. At the very least, drafters of both instruments could have considered it to be as much a cultural right as a social, economic, civil and political right given the fundamental role it was considered to play in supporting the realisation of other rights in all categories. Permanently subsuming the right to science under the banner of cultural rights, both ideologically, and textually in these two key human rights instruments, may have blunted the effect and the perception of the right over time.

\section{The Scope of the Right to Science}

The right to science, as framed by the UDHR, states that 'everyone has the right freely [...] to share in scientific advancement and its benefits ${ }^{\text {}}{ }^{76}$. The right to science in the ICESCR went beyond the parameters of the right in the UDHR as Article 15 of the ICESCR didn't just give individuals a right of access to scientific advancement, ${ }^{77}$ it also created an obligation on states to ensure that steps were put in place to realise the 'the conservation, the development and the diffusion of science'78, and to 'respect the freedom indispensable for scientific research and

creative activity' ${ }^{79}$ Moreover states explicitly recognised the benefits of international 
cooperation in the field of science in the context of this right. ${ }^{80}$ As such, the right as formulated in the ICESCR represents a considerable expansion on that which was included in the UDHR and therefore, unsurprisingly, during the drafting of the ICESCR, there were major discussions on the scope of the right to science.

A notable feature of the development of the right to science in the ICESCR was the concern raised over the way in which key terms might be interpreted differently around the world. ${ }^{81}$ During the Third Committee's ninth session in 1954, the Canadian delegate, Mrs. Montgomery, felt that there were certain provisions in the draft covenant, in particular in relation to the right to science, which would require explanation if the covenant were to have the same meaning for all countries. ${ }^{82}$ The Third Committee began to discuss the right to science specifically during their twelfth session in 1957. At the outset it was agreed that while draft Article 16 (as the right was then numbered) referred to important human rights, 'certain concepts or notions contained therein might still be in the process of evolution. ${ }^{83}$ These comments were first advanced by the representative from UNESCO, Mr. Maheu, who commented that the right to science differed from other articles in the covenant precisely because certain concepts were evolving rapidly at that time 'from both the legal and the philosophical points of view' ${ }^{84} \mathrm{He}$ continued by suggesting that 'since the very freedom of the human mind was involved [...] [t]he Committee should $[\ldots]$ take care that that freedom was respected if it did not wish to destroy what it sought to protect. ${ }^{95}$ The delegate from Jordan, Mrs. Haikal, concurred with the views of the UNESCO delegate by saying that the notions in draft Article 16 were 'much less clearly defined than, for instance, in education. ${ }^{86}$ Her preference was that, unless the Committee considered the adoption of more precise definitions, draft Article 16 should be restricted to a statement of principle. ${ }^{87}$ While certain proposed amendments, such as those related to the purpose of science, were rejected because of their imprecision, key terms that did make the cut were never truly defined during the drafting process. The following sub-sections explore the 
way in which drafters at the time understood the four different aspects of the right to science as enumerated in the ICESCR.

\section{a. Sharing in Scientific Advancement and Progress}

Article 15(1)(b) of the ICESCR recognises 'the right of everyone to enjoy the benefits of scientific progress and its applications.' This differs from the right as captured in the UDHR, which refers to sharing in scientific advancement and its benefits rather than enjoying scientific progress and its applications. The preliminary draft of the right to science prepared by the UN Secretariat suggested that ' $[\mathrm{e}]$ veryone has the right to $[\ldots]$ share in the benefits of science. ${ }^{88}$ The precise meaning of the phrase share in the benefits of science was unclear to some delegates at the time and the Chinese delegate requested clarification. ${ }^{89}$ An explanation was provided by the Chilean delegate, Mr. H. Santa-Cruz, to the Drafting Committee in June 1947. To him, the right as a whole meant that 'scientific inventions should belong to society and be enjoyed by all. ${ }^{90}$ The phrase to share in scientific advancement, as opposed to 'progress' was proposed by the Chinese delegate during the drafting of the UDHR, drawing upon the work of Francis Bacon in that regard. ${ }^{91}$ However, no real interrogation of the definition of scientific advancement, or what it means to freely share in the benefits of such was engaged in by the drafters of the UDHR before including it in the final text adopted by the UN General Assembly.

During the drafting of the ICESCR by the Commission on Human Rights' in their seventh session, UNESCO submitted two proposals for the article on the right to science: one long article, which explained the contours of the right in detail, ${ }^{92}$ and one more succinct article that mirrored the brevity of Article 27 of the UDHR.${ }^{93} \mathrm{Mr}$. Havet, UNESCO's delegate at the time, recognised that there was a concurrent need for both precision and the greatest possible brevity ${ }^{94}$ in describing the right to science. However, neither proposal appears to have been considered in great depth by states. Had the longer proposal been discussed in depth, it could 
have, perhaps, helped to establish a common understanding, at least at the time of drafting, of aspects of the right, such as support for scientific research and guaranteeing scientific freedom, which remain, arguably, open to interpretation in the ICESCR.

As an example of the different ways in which states might interpret key terms in this regard, it is illuminating to examine discussions focused on the meaning of the word progress, which was preferred in the ICESCR over the word advancement which was used in the UDHR. During the Commission on Human Rights' eighth session, the USSR argued that '[t]he word "progress" was perfectly clear'. ${ }^{95}$ To the USSR, progress meant 'the general advance of mankind towards a better civilization.' 96 However, the USSR continued to press the perspective that ' $[\mathrm{p}]$ rogress and the maintenance of peace were inseparable concepts. ${ }^{97}$ Many states disagreed with this point of view, exemplifying the extent to which states might interpret key terms differently. The delegate from the United Kingdom suggested that

'[e]ven if it were admitted that scientific development should be governed by certain ideas, they should not be vague and ill-defined notions such as progress and democracy. Those words had been abused to such an extent that they had lost any definite meaning. If scientific development were to be subordinated to them, certain States might interpret them in a highly dangerous manner., 98

The USSR and the United Kingdom held very different views on the manner in which the term progress ought to be understood, and the divergence in opinion is indicative of the views held more widely by states. Even though it is a crucial element of the right, there was no common understanding amongst drafters at the time as to what amounted to scientific progress and what did not.

Other key terms were not interrogated to any great extent either during the drafting of the ICESCR. For example, during the Commission on Human Rights eighth session, the Egyptian 
delegate sought clarification on the question of whether the term 'scientific research' applied also to the social sciences ${ }^{99}$, and the Chair of the Commission 'confirmed that the term applied to every possible branch of research. ${ }^{100}$ However clarification on what the benefits of scientific progress might mean - how the positive and negative effects of scientific research might be determined for the purposes of this right so that only those results conferring a benefit are implicated - was never discussed. To these key aspects of Article 15(1)(b) the drafting history provides no clear interpretive guidance.

Determining the scope of the right to science, even between the aspects of the right common to both the UDHR and the ICESCR, was clearly not given sufficient consideration during the drafting process. Perhaps at the time, progress in science was more evident than it is today. For example, scientific progress in the field of geoengineering may confer benefits on one part of the world and detriment in another - how to assess such developments under Article 15(1)(b) of the ICESCR is certainly not clarified by the drafting history. Indeed during the Third Committee's twelfth session concerning definitions in the ICESCR more generally, the delegate from Iraq, Mrs. Afnan, said that 'the debate has not removed all of her misgivings concerning article 16. ${ }^{\prime 101}$ She insisted that '[p]aragraph $1(\mathrm{~b})$ was so vague and general that the legal obligation undertaken by States in that regard was by no means clear. ${ }^{102}$ Eide has observed that 'the state and its relevant professionals may have to form [a] judgment as to what constitutes progress and what does not... In many cases, the question is open to doubt and to controversial debates'. ${ }^{103}$ This conclusion is easily supported by the lack of consensus on the meaning of terms during the drafting of the relevant provisions in both the UDHR and ICESCR.

\section{b. Conservation, Development and Diffusion of Science}

An element of the right to science that was not included in the UDHR, but which was inserted during the drafting of the ICESCR as Article 15(2), is the obligation on states to take steps to 
conserve, develop and diffuse science in realising the right enumerated in Article 15(1)(b). McGoldrick asserts that this provision was necessary because the right to participate in culture or science can only be realised if culture or a body of scientific knowledge exists, so to speak. ${ }^{104}$ The expansion in the scope of the right in this way began during the Commission on Human Rights' seventh session in 1951. Early discussions at this time involved interventions such as those attributed to UNESCO, who argued that the right to science 'was largely dependent on the work done by bodies which, in certain countries, were not responsible to the public authorities'. ${ }^{105}$ As such, UNESCO's view was that states ought to be required to take steps to promote and co-ordinate access to the benefits of scientific progress by everyone. ${ }^{106}$ To UNESCO, '[e]njoyment of the benefits of scientific progress implied the dissemination of basic scientific knowledge, especially knowledge best calculated to enlighten men's minds and combat prejudices, co-ordinated efforts on the part of States, in conjunction with the competent specialized agencies, to raise standards of living, and a wider dissemination of culture through the processes and apparatus created by science. ${ }^{107}$ Therefore to UNESCO at the time, it was important that the enforceable right in the ICESCR include an obligation on states to put in place the conditions and frameworks necessary to ensure that all individuals would have access to and benefit from scientific progress and its applications.

During the Commission on Human Rights' consideration of the draft ICESCR in their eighth session in 1952, the delegate from the USA, Eleanor Roosevelt, presented an amendment ${ }^{108}$ to the right to science with the intention of making it clearer, something that the UN General Assembly had requested of all articles by that time. In essence, the amendment echoed the views shared by UNESCO the previous year, and it stipulated that the 'full attainment of this right requires the conservation the development and the diffusion of science and culture'109 There was a clear attempt to clarify the contours of the right to science in the amendment proposed by the USA, as Mrs. Roosevelt explained that 
[e]mphasis had been laid upon the freedom necessary for scientific research and creation because the original text called merely for the right to enjoy the benefits of scientific progress, or, in other words, simply the right to enjoy the results of scientific research, whereas what was really required was to ensure conditions in which such research could be freely conducted. ${ }^{, 10}$

As a result of this awareness amongst states that the right to science needed states to undertake additional obligations, beyond those contained in the UDHR, the scope of the right to science was expanded. But the precise meaning of what it means to conserve, develop and diffuse science was not clarified at any point during the drafting of the ICESCR. Therefore the drafting history cannot be relied upon as a supplementary means of interpretation to understand what conserving science involves, to appreciate how the obligation to develop science can be satisfied without influencing the direction that scientific research should take, or to determine the lengths to which states are expected to go in diffusing scientific knowledge, nationally and internationally.

\section{c. Freedom Indispensable for Scientific Research}

A further expansion on the scope of the right to science is the undertaking by states, in Article 15(3) of the ICESCR 'to respect the freedom indispensable for scientific research and creative activity'. In 1953, the UN Secretary General made it known to the Commission on Human Rights that he considered the word indispensable to be a potential weakness. ${ }^{111}$ If the provision was narrowly interpreted as requiring only such freedom as was strictly necessary for scientific research, the right in question might be unduly limited in his view. ${ }^{112}$ Instead, the UN Secretary General suggested that the wording of this part of Article 15 be changed to omit the reference to indispensable freedom. ${ }^{113}$ The Commission on Human Rights did not make this change, but states expressed similar concerns during the Third Committee's twelfth session in $1957 .{ }^{114}$ For 
example, the Philippines felt that as it was the State that would determine the degree of freedom considered indispensable', ${ }^{115}$ retaining that word might have a 'limiting or nullifying, ${ }^{116}$ effect on the scope of the right to science.

However, during these discussions in the Third Committee, other states perceived the term indispensable to be necessary so that the state could 'impose the limitations strictly required by national security, public order and morality'. ${ }^{117}$ For example, United Kingdom felt that 'no State was in a position to allow absolute freedom'118 and 'the restrictions imposed by the requirements of public order and national security were inevitable, particularly with regard to scientific research. ${ }^{119}$ The United Kingdom raised concerns over the capacity of the state to impose necessary limitations on the work of scientists if the work indispensable were removed. ${ }^{120}$ There were certain obvious contradictions inherent in this position: most states were unwilling to support the USSR/Czechoslovakian proposal suggesting that the right to science be directed towards certain ends, namely peace and democracy, because they felt that states would be given too much power and influence over scientific research. Yet retaining the word indispensable gave states the latitude to intervene in scientific research, seemingly however they saw fit. This contradiction was noted by the Greek delegate. ${ }^{121}$ However, reconciling inherent contradictions in negotiating positions appears not to have been of concern to the Third Committee at the time because the word indispensable was ultimately retained by the Committee ${ }^{122}$ and adopted by the UN General Assembly as part of the final text of the ICESCR.

\section{d. International Cooperation in Science}

The final provision in Article 15 encourages states to recognise the benefits of international cooperation in the field of science. ${ }^{123}$ This sentiment was debated extensively in the context of proposals that had been made by the USSR and Czechoslovakia to determine that scientific 
progress should serve certain ends, namely that of peace and democracy. In the Third Committee's twelfth session 1957, the delegate from Czechoslovakia, Mrs. Leflerova, felt that international cooperation in the field of science should not only be explicitly encouraged by the ICESCR, she felt that states should have an obligation to cooperate and work together in this regard. ${ }^{124}$ A proposal was tabled to incorporate this sentiment into the draft article on the right to science. The delegate from the Ukrainian Soviet Socialist Republic, Mrs. Bilai, supported this amendment, stating that 'international co-operation was an important factor in the spiritual and material advancement of all mankind and of each nation in particular. ${ }^{, 25}$ The Pakistani delegate, Mr. Chaudhuri stated that there would certainly be benefits to international cooperation in states where scientific progress had been slow to develop. ${ }^{126}$

However, the sentiment behind the requirement for international cooperation in the field of science was not universally endorsed. The United Kingdom, for example, disagreed with the proposal as it felt that the idea was too general in scope and more suited to a future resolution. The delegate from the United Kingdom felt that if the Committee wished to 'prepare an international instrument which would be orderly and not a rag-bag, it would have to be ruthless and refrain from introducing into the Covenant generalities, however well-intentioned.' ${ }^{127}$ Given the mixed views of states regarding obligations to cooperate internationally - a requirement that could potentially create extraterritorial obligations - an amendment to remove any legally binding obligations on states to cooperate was adopted. ${ }^{128}$ Therefore Article 15(4) of the ICESCR encourages states to cooperate in the field of science but does not oblige them to do so.

\section{Conclusion}

The human right to science is perhaps more relevant today than it has ever been, with access to innovations in healthcare, information technology and climate-friendly energy production 
being some of the defining issues of present-day life. Through the Universal Declaration of Human Rights and the International Covenant on Economic, Social and Cultural Rights, states parties have an obligation to facilitate access to the benefits of scientific progress whilst also fostering an environment in which such progress can be freely made, all while recognising the advantages of international cooperation in that regard. However, in the absence of authoritative interpretations of the right to science - from judicial proceedings or the Committee on Economic, Social and Cultural Rights - the travaux préparatoires of the UDHR and ICESCR are the most comprehensive touchstones that exist from which an understanding of the right to science can be derived. This article examined the drafting history of the right to science over a 20-year period, from 1946 to 1966 to determine how the original drafters of the right understood it and to determine if a common understanding of the right, which is not at present very well understood, ever existed. The results of this historical survey bring fresh perspectives to the debate, perspectives which may inform contemporary and future interpretations of the right.

While the inclusion of the right to science in the UDHR and ICESCR may have been a case of having the right person involved at the right time, it is evident from the procedural drafting history of the right that states were generally in favour of the right to science from the time that John Humphrey proposed it in the initial draft that he prepared on behalf of the UN Secretariat. This high-level agreement to the inclusion of the right to science as an autonomous and fundamental part of the new human rights architecture that was emerging throughout the 40s, $50 \mathrm{~s}$ and 60 s confirms that the right has been acceptable and uncontroversial since the beginning. However, given the degree of consensus over the inclusion of the right in the UDHR and ICESCR, it is surprising that the right has not been more dominant in discussions of positive and negative scientific developments in the decades since. Perhaps a lack of consensus as to the nature and scope of the right, from the time of its very inception, has obfuscated the 
clear utility of both Article 27 of the UDHR and Articles 15(1)(b), 15(2), 15(3), and 15(4) of the ICESCR. Although the right to science can be argued to have clear linkages with the right to culture, placing too much emphasis on the interconnected nature of the rights to science and culture, as the former UN Special Rapporteur has arguably done ${ }^{129}$ may have perpetuated the impression that the right to science continues to have greater application in the cultural sphere than in relation to rights that may be classified as civil, political, economic, or social. ${ }^{130}$

However, the implications of classifying the right to science as a cultural right do not appear to have been at the forefront of drafters' minds during the formulation of either the UDHR or the ICESCR. While scientific progress was never considered to be a civil or political right during the drafting of the UDHR or ICESCR, it could now be considered, in various ways, to belong to all five categories of rights - civil, political, economic, social and cultural. It will be interesting to see if the right to science, through future interpretations and applications, can transcend the box into which it was inadvertently placed by drafters of the UDHR and ICESCR.

Concerning the scope of the right to science, it is clear from the outset that some states had concerns over the extent to which key terms within the right could be interpreted differently, because clarification of such terms had not been achieved during negotiations. No real interpretive guidance is to be found in the drafting history of the right for key terms such as scientific progress, or for what it means to conserve, develop, and diffuse science. Moreover, while the obligation in Article 15(3), to provide the freedom indispensable for scientific research, appears to be straightforward, the drafting history shows that some states viewed this choice of words as an opportunity to exert control over the extent to which scientific research could be conducted within their jurisdiction, an interpretation that other states and the UN Secretary-General of the day, were opposed to. The drafting history demonstrates that both interpretations may be valid, and this may affect the extent to which scientific progress can be made in any given circumstance - a consequence that would undermine the rationale behind 
the very existence of the right to science in the first place. Finally, understanding Article 15(4) of the ICESCR is not quite as critical as the other provisions, as the majority of states decided when drafting that they did not want to be obliged to cooperate with each other in the field of science, and so the provision merely asks states to recognise the benefits of doing so; it does not require them to do so.

Understanding the right to science and the specific nature and scope of the obligations it creates for states will be crucial if human rights are to have any meaningful role in regulating the effects of scientific and technological progress on the lives and livelihoods of individuals around the world. Examining the drafting history of the right to science anchors the development of such an understanding, for a brief moment in time, to the point in human history when the right was first formally and internationally recognised. The analysis of the travaux préparatoires in this article has shown that some interpretive guidance may be derived from the drafting history of the UDHR and ICESCR, but it also clearly shows that the right is far from being perfectly drafted. By and large, much work must be done in the present day to ensure that a common understanding of the right to science is agreed upon - something that the original drafters failed to achieve throughout the $40 \mathrm{~s}, 50 \mathrm{~s}$ and $60 \mathrm{~s}-$ if the right to science is ever going to step forward from the vanishing point of human rights discourse in the future.

\footnotetext{
${ }^{1}$ Asbjorn Eide, 'Cultural Rights as Individual Human Rights' in Economic, Social and Cultural Rights', ed. Asbjorn Eide, Catarine Krause, and Allan Rosas, $2^{\text {nd }}$ ed. (Martinus Nijhoff, 2001) 289-302, 289.

${ }^{2}$ The right to science in this article is used as a term of convenience to refer to either or both Article 27 of the UDHR, Article 15 of the ICESCR. It is not the intention of the author to change the nature of the right or simplify it, as McGoldrick points out that the nature of the right to science is not necessarily a right to something, as most civil and political rights are, but more a right of participation. Dominic McGoldrick, 'Culture, Cultures, and Cultural Rights' in Economic, Social and Cultural Rights in Action, ed. Mashood A. Baderin and Robert McCorquodale, (OUP, 2007) 447-473, 453.

${ }^{3}$ William Schabas, 'Study of the Right to Enjoy the Benefits of Scientific and Technological Progress and its Applications', in Human Rights in Education, Science and Culture: Legal Developments and Challenges, ed. Yvonne Donders and Vladimir Volodin (Routledge, 2007), 273-308, 274. See also Eide, supra n. 1, at 289 remarking that 'Cultural rights are at the end of the rights listed in both instruments, and appear almost as a remnant category.'

${ }^{4}$ Indeed Schabas has observed that the right to science in general 'has been barely addressed in the academic literature.' Schabas, supra n. 3, 274. This is something that Chapman agrees with in UN Committee on Economic,
} 
Social and Cultural Rights (24 $4^{\text {th }}$ Session) 'Approaching Intellectual Property as a Human Right: Obligations Related to Article 15(1)(c)' (3 October 2000) UN Doc E/C.12/2000/12, para 25. Shaver is also in agreement. See Lea Shaver, 'The Right to Science and Culture' (2010) Wisconsin Law Review 121, 125-126

${ }^{5}$ The Committee on Economic, Social and Cultural Rights have held a General Discussion Day to explore the right to science ahead of the expected development of a General Comment. See Committee on Economic Social and Cultural Rights 'General discussion on a draft general comment on article 15 of the International Covenant on Economic, Social and Cultural Rights: on the right to enjoy the benefits of scientific progress and its applications and other provisions of article 15 on the relationship between science and economic, social and $\begin{array}{lllll}\text { cultural } & \text { rights', } & \text { Geneva, } & 9 & \text { October }\end{array}$ <https://www.ohchr.org/EN/HRBodies/CESCR/Pages/Discussion2018.aspx> accessed 27 June 2019.

${ }^{6}$ Ben Saul, The International Covenant on Economic, Social and Cultural Rights Travaux Preparatoires, (OUP, 2016), xciv; also William Schabas, The Universal Declaration of Human Rights: The Travaux Préparatoires, (CUP, 2013), xxxviii

${ }^{7}$ Schabas has observed that 'Given its obvious significance, it is quite striking how rarely the norm is actually invoked' in Schabas, supra n. 3, 302. McGoldrick has described cultural rights in general as 'the failed Cinderella of the human rights lexicon - pretty to picture but they don't quite make it to the ball' in McGoldrick, supra n. 2, 447.

${ }^{8}$ See Shaver, supra n. 4, 127.

${ }^{9}$ United Nations, Vienna Convention on the Law of Treaties, 23 May 1969, United Nations Treaty Series, Vol. 1155 , p. 331, Article 32 . The ordinary meaning of terms should be discerned according to the provisions of Article 31. Indeed Schabas has remarked that 'When a document such as the Declaration is being negotiated, participating States are quite conscious of the fact that they are constructing a documentary record that will be consulted in the future and quite possibly invoked in legal disputes. They make statements and reservations that are intended to condition the future interpretation of the text that is being adopted.' Schabas, supra n. 6, xxxviii

${ }^{10}$ Schabas, supra n. 3, 274. This article focuses predominantly on Articles 15(1)(b), 15(2), 15(3) and 15(4).

${ }^{11}$ As Schabas has observed 'as with all international norms, the starting point of the enquiry must be their drafting by international institutions' in Schabas, supra n. 3, 274

${ }^{12}$ Saul, supra n. 6, xcv - xcviii

${ }^{13}$ Ibid. xcviii; See also UN ECOSOC 'Report of the Commission on Human Rights' (27 March 1947) UN Doc E/383; Approved in UN ECOSOC 'Resolutions Adopted by the Economic and Social Council on 28 March 1947' (22 April 1947) UN Doc E/325, 2; Eleanor Roosevelt was elected as chair of the small group of experts that made up the Commission on Human Rights' membership; See Commission on Human Rights ( $1^{\text {st }}$ Session) 'Report of the Drafting Committee to the Commission on Human Rights' (1 July 1947) UN Doc E/CN.4/21, 2

${ }^{14}$ UN Commission on Human Rights 'Draft Outline of International Bill of Rights' (4 June 1947) UN Doc E/CN.4/AC.1/3; Reproduced in Commission on Human Rights UN Doc E/CN.4/21, supra n. 13, Annex A. See also Agenda Item 7 in UN Commission on Human Rights 'Provisional Agenda for the Third Meeting of the First Session (24 January 1947) UN Doc E/CN.4/3 and Saul, supra n. 6, c.

${ }^{15}$ Commission on Human Rights UN Doc E/CN.4/21, supra n. 13, Article 44

${ }^{16}$ Johannes Morsink, The Universal Declaration of Human Rights: Origins, Drafting and Intent, (University of Pennsylvania Press, 1999), 217

${ }^{17}$ See Commission on Human Rights 'Drafting Committee International Bill of Rights' (11 June 1947) UN Doc E/CN.4/AC.1/3/Add.1. Brazil referred to Article 173 "The sciences, letters, and arts are free" and Art 174 "Support of culture is a duty of the State. The law shall promote the creation of research institutes particularly in connection with establishments of higher education" of its Constitution of 18 September 1946; Saudi Arabia, referred to Article 23 of its Constitution of 29 August 1926, "Public education comprises the diffusion of science, education and the arts, and the opening of libraries, schools and religious institutes, great care and attention being taken to act in accordance with the foundations of religion in all the Kingdom of the Hejaz"; Uruguay, referred to Article 62 of its Constitution of 24 March 1934 (amended in 1942), "Official free primary, intermediate, superior, industrial and artistic instruction, and physical education is declared a social need; also the creation of scholarships for cultural, scientific, and industrial improvement and specialization, as well as the establishment of popular libraries"; and Yugoslavia, referred to Article 37(2) of its Constitution, "The State assists science and art with a view to developing people's culture and prosperity". 
${ }^{18}$ UN ECOSOC, 'Draft Declaration of the International Rights and Duties of Man' (8 January 1947) UN Doc $\mathrm{E} / \mathrm{CN} \cdot 4 / 2$

${ }^{19}$ UNGA First Committee, 'Letter from the Representative of Chile to the Secretary-General' (6 November 1946) UN Doc A/C.1/38; UN ECOSOC UN Doc E/CN.4/2, supra n. 18

${ }^{20}$ UNGA Res 43 (I) (11 December 1946) UN Doc A/RES/43(I) and UNGA 'Draft Declaration on Fundamental Human Rights and Freedoms' (10 December 1946) Un Doc A/234, which later become the American Declaration of the Rights and Duties of Man.

${ }^{21}$ Article XV read as follows: "Every person has the right to share in the benefits occurring from the discoveries and inventions of science, under conditions which permit a fair return to the industry and skill of those responsible for the discovery of invention. The state has the duty to encourage the development of the arts and science, but it must see to it that the laws for the protection of 'trademarks, patents and copyrights are not used for the establishment of monopolies which might prevent all persons from sharing in the benefits of science. It is the duty of the state to protect the citizen against the use of scientific discoveries in a manner to create fear and unrest amongst the people." UN ECOSOC UN Doc E/CN.4/2, supra n. 18, Article XV

22 'against the use of scientific discoveries in a manner [that would] create fear and unrest among the people'. UN ECOSOC UN Doc E/CN.4/2, supra n. 18, Article XV

${ }^{23}$ Inter-American Juridical Committee 'Draft Declaration of the International Rights and Duties of Man and Accompanying Report' (1946) 40 American Journal of International Law Supplement 3, 108 para 3

${ }^{24}$ Ibid. 110 para 1

${ }^{25}$ Ibid. 109 para 3

${ }^{26}$ Ibid.

${ }^{27}$ Saul, supra n. 6, c, footnote 29

${ }^{28}$ These views are captured in a subsequent address made by Laugier during the first session of the Commission on Human Rights in 1946. UN Commission on Human Rights, 'Summary Record of Meetings' (1 May 1946) UN Doc E/HR/6, 2. See also Johannes Morsink, supra n. 16, 222-223

${ }^{29}$ By combining art with science, Morsink has observed that Humphrey may have reflected a point of view based on his own personal interests and experiences. Morsink, supra n. 16, 218

${ }^{30}$ References to the right to science submitted by states were contained in a few national constitutions which referred to science, culture and the arts together. Despite the strong rationale given by the Inter-American Juridical Committee for treating the right to science as an independent right, Humphrey's draft perhaps deliberately, perhaps accidentally, struck the right note for states at the time. Given subsequent debates, had Humphrey decided to include references to the purpose of science and to intellectual property, perhaps states would not have received the right as openly as they did in the early stages of negotiation. See Commission on Human Rights UN Doc E/CN.4/AC.1/3/Add.1, supra n. 16. For further discussion on the debates in the travaux preparatoires concerning the purpose of science, see Richard Pierre Claude, Science in the Service of Human Rights, (University of Pennsylvania Press, 2002), 27-39 and William Schabas, 'Looking Back: How the Founders Considered Science and Progress in their Relation to Human Rights'(2015) 4 European Journal of Human Rights 504

${ }^{31}$ Saul, supra n. 6, c

${ }^{32}$ Morsink, supra n. 16, 6. See also Saul, supra n. 6, c

${ }^{33}$ Commission on Human Rights UN Doc E/CN.4/21, supra n. 13, para 12

${ }^{34}$ Ibid. para 14

${ }^{35}$ UN Commission on Human Rights, 'Text of Letter from Lori Dukeston, the United Kingdom representative on the Human Rights Commission, to the Secretary-General of the United Nations' (5 June 1947) UN Doc E/CN.4/AC.1/4

${ }^{36}$ The Drafting Committee considered the first draft declaration prepared by Cassin and the temporary Working Group, in which the right to science was Article 43 and the right to intellectual property was Article 44, and requested the Working Group to revise the draft declaration based on these discussions. See Commission on Human Rights UN Doc E/CN.4/21, supra n. 13, para 17. Cassin who prepared a second draft in which the right to science, as originally conceived of by the UN Secretariat, was renumbered as Article 37 and the new article on intellectual property rights which Cassin had introduced in the previous draft became Article 38: See also UN Commission on Human Rights, 'Revised Suggestions Submitted by the Representative of France for Articles of the International Declaration of Rights' (20 June 1947) UN Doc E/CN.4/AC.1/W.2/Rev.2, 7. The Drafting 
Committee discussed this second draft and revised it before submitting to the Commission on Human Rights for consideration. In the draft submitted to the Commission on Human Rights, the right to science was renumbered to Article 35. The most notable change to the article was that the clause 'to share in the benefits of science' became 'to share in the benefits that result from scientific discoveries': Commission on Human Rights UN Doc E/CN.4/21, supra n. $13,80-81$

${ }^{37}$ UN Commission on Human Rights 'Suggestions Submitted by the Representative of France for Articles 7-32 of the International Declaration of Rights' (18 June 1947) UN Doc E/CN.4/AC.1/W.2/Rev.1, 8 Articles 43 and 44.

${ }^{38}$ The inclusion of intellectual property rights in the UDHR and ICESCR goes beyond the issues at focus in this article - the nature and scope of the right to science. There has been good scholarly consideration of the content of the human right to moral and material interests in artistic and scientific creations, and further consideration of the impact that intellectual property rights might have on the realisation of other human rights. However, comparatively little attention has been given to examining and developing the content of the right to science. See supra n. 4. As a result, this article responds to the clear need to develop an understanding of the normative content of the right to science, so that analysis of the relationship between this right, the right to intellectual property, and other human rights, can be better understood. For insights into the inclusion of intellectual property rights in the UDHR and ICESCR, and intellectual property rights as human rights see the papers prepared by Maria Green and Audrey Chapman for the UN Committee on Economic Social and Cultural Rights respectively at UN Committee on Economic, Social and Cultural Rights, 'Drafting History of the Article 15 (1) (c) of the International Covenant on Economic, Social and Cultural Rights' (9 October 2000) UN Doc E/C.12/2000/15; UN Committee on Economic, Social and Cultural Rights $\left(24^{\text {th }}\right.$ Session) 'Approaching Intellectual Property as a Human Right: Obligations Related to Article 15(1)(c)’ (3 October 2000) UN Doc E/C.12/2000/12; Aurora Plomer, Patents, Human Rights and Access to Science, (Edward Elgar Publishing, 2015); and also Shaver, supra n. 4.

${ }^{39}$ Saul, supra n. 6, cxvi

${ }^{40}$ UNGA Res 421 (V) (4 December 1950) UN Doc A/Res/421(V), Section E; UN ECOSOC Res 349 (XII) (23 February 1951) UN Doc E/Res/349(XII)

${ }^{41}$ And discussed as draft Article 30 of a single covenant by the Commission on Human Rights during their seventh session in 1951: UN ECOSOC (13 ${ }^{\text {th }}$ session) 'Report to the Economic and Social Council on the seventh session of the Commission on Human Rights' (1951) UN Doc. E/1992, 24. The text of the draft article 30 read as follows: '1. The States Parties to the Covenant undertake to encourage by all appropriate means the conservation, the development and the diffusion of science and culture. 2. They recognize that it is one of their principal aims to ensure conditions which will permit everyone: (o) To take part in cultural life; (6) To enjoy the benefits of scientific progress and its applications.'

${ }^{42}$ Commission on Human Rights $\left(7^{\text {th }}\right.$ Session) 'Summary Record of the Two Hundred and Thirtieth Meeting' (29 June 1951) UN Doc E/CN.4/SR.230, 7

${ }^{43}$ The Guatemalan delegate, Mr. Garcia Bauer, expressed views of this nature when the draft covenant produced by the Commission on Human Rights in 1951 was considered by the UN General Assembly's Third Committee. See UNGA Third Committee (6 ${ }^{\text {th }}$ Session) $360^{\text {th }}$ Meeting (5 December 1951) UN Doc A/C.3/SR.360, para 25: ' $\mathrm{t}$ ] he covenant should not be limited, however, to establishing a scale of values similar to that in the Universal Declaration of Human Rights, but should state the principle of the responsibility of the State with regard to the implementation of fundamental human rights'. See also at para 26 where he felt that Article 30 'laid down that the States parties to the covenant should undertake to encourage by all appropriate means the conservation, the development and the diffusion of science and culture.'

${ }^{44}$ UNGA Res 543 (VI) (5 February 1952) UN Doc A/Res/543(VI). The decision to draft two covenants was at the suggestion of the Third Committee, see UNGA ( $6^{\text {th }}$ Session) $374^{\text {th }}$ Plenary Meeting (4 $4^{\text {th }}$ February 1952$)$ UN Doc A/PV.374, para 33

${ }^{45}$ UNGA Res 543 (VI) (5 February 1952) UN Doc A/Res/543(VI).; For further discussion see Saul, supra n. 6 , cxv-cxvii

${ }^{46}$ Commission on Human Rights ( $8^{\text {th }}$ Session) (14 May 1952) UN Doc E/CN.4/666/Add.5, rather than article 30 of a single draft convention on human rights containing both economic, social, cultural, civil and political rights. See also UN ECOSOC (14 ${ }^{\text {th }}$ Session) 'Report to the Economic and Social Council on the eighth session of the Commission on Human Rights’ (1952) UN Doc E/CN.4/669, para 127 and Annex 1A 
${ }^{47}$ See report of the $9^{\text {th }}$ and $10^{\text {th }}$ sessions of the Commission on Human Rights which repeat the draft of Article 16 that was agreed during the $8^{\text {th }}$ session of the Commission: UN ECOSOC $\left(16^{\text {th }}\right.$ Session $)$ 'Report of the Ninth Session of the Commission on Human Rights' (1953) UN Doc E/CN.4/689 and UN ECOSOC (18 ${ }^{\text {th }}$ Session) 'Commission on Human Rights Report of the Tenth Session' (1954) UN Doc E/CN.4/705.

${ }^{48}$ UNGA ( $9^{\text {th }}$ Session) 'Report of the Third Committee' (29 November 1954) UN Doc A/2808, para 7

${ }^{49}$ Céline Romainville, 'Defining the Right to Participate in Cultural Life as a Human Right' (2015) 33(4) Netherlands Quarterly of Human Rights 405-436

${ }^{50}$ Cass R. Sunstein, 'Incompletely Theorized Agreements' (1885) 108(7) Harvard Law Review 1733-1772

${ }^{51}$ Commission on Human Rights UN Doc E/CN.4/21, supra n. 13, 81. See discussions of the Drafting Committee in Commission on Human Rights ( $1^{\text {st }}$ Session) (3 July 1947) UN Doc E/CN.4/AC.1/SR.15, 3-4. Other states, such as France, proposed that the right to science be included not as a stand-alone article, but as a constituent element of the right to rest and leisure. See Commission on Human Rights ( $3^{\text {rd }}$ Session) 'Communication received from the French Government' (6 May 1948) UN Doc E/CN.4/82/Add.8, 6, Article 25. See also Commission on Human Rights 'Report of the Drafting Committee to the Commission on Human Rights' (21 May 1948 UN Doc E/CN.4/95, 12, Article 29 and Commission on Human Rights UN Doc E/CN.4/21, supra n. 13, Article 42

${ }^{52}$ Commission on Human Rights UN Doc E/CN.4/21, supra n. 13, 81

${ }^{53}$ In this context, 'Promethian' refers to the daring creativity and innovation of the drafters as a whole, and John Humphrey in particular, in deciding to include a right to science in the UDHR where no such right manifestly existed before this document. See Merriam-Webster < https://www.merriamwebster.com/dictionary/Promethean> accessed 7 November 2019

${ }^{54}$ UN Commission on Human Rights ( $3^{\text {rd }}$ session), 'Summary Record of the Seventieth Meeting', (21 June 1948) UN Doc E/CN.4/SR.70, 4

55 UNGA Third Committee ( $3^{\text {rd }}$ Session), Hundred and Fiftieth Meeting (20 November 1948) UN Doc A/C.3/SR.150, 619

${ }^{56}$ UNGA Third Committee (12 ${ }^{\text {th }}$ Session) $796^{\text {th }}$ Meeting (31 October 1957) UN Doc A/C.3/SR.796, para 27

${ }^{57}$ UN Commission on Human Rights, ( $7^{\text {th }}$ Session) 'Summary Record of the Two-Hundred and Twenty-Eighth Meeting' (28 June 1951) UN Doc E/CN.4/SR.228, 11

${ }^{58}$ Ibid.

${ }^{59}$ Ibid.

${ }^{60}$ As an example of such debates, see UNGA Third Committee 'Hundred and Twenty-Seventh Meeting' (9 November 1948) UN Doc A/C.3/SR.127, 390-402. The link between freedom of thought and the right to science was raised by Mr. Pavlov, the delegate from the USSR, during a vote on the right to freedom of religion. He expressed concern that 'Science had a right to protection on the same terms as religion. Out of respect for the heroes and martyrs of science, those words [relating to freedom of thought] should not be deleted.' UN Commission on Human Rights ( $3^{\text {rd }}$ Session) 'Summary Record of the Sixtieth Meeting' (23 June 1948) UN Doc E/CN.4/SR.60, 10. He further expressed sentiments that elaborated on these views, stating that 'The USSR delegation placed particular emphasis on freedom of thought which it was necessary to sanction in order to promote the development of modern sciences and which took account of the existence of free-thinkers whose reasoning had led them to discard all old-fashioned beliefs and religious fanaticism. The times when scientists were condemned to be burnt at the stake were past, and science occupied a most important place in human life.' UNGA Third Committee 'Hundred and Twenty-Seventh Meeting' (9 November 1948) UN Doc A/C.3/SR.127, 391. The Uruguayan delegate, Mr. Jiminez de Arechaga, expressed similar views at 401 of UN Doc A/C.3/SR.127 that 'freedom of thought should be extended particularly to the realms of politics and science.'

${ }^{61}$ UN Commission on Human Rights, ( ${ }^{\text {th }}$ Session) 'Summary Record of the Two-Hundred and Ninety-Second Meeting' (27 May 1952) UN Doc E/CN.4/SR.292, 7

${ }^{62}$ Article XV in UN ECOSOC UN Doc E/CN.4/2, supra n. 18

${ }^{63}$ Human Rights Council, 'Report of the Special Rapporteur in the field of cultural rights, Farida Shaheed: The right to enjoy the benefits of scientific progress and its applications' UN Doc A/HRC/20/26 14 May 2012, 3-4.

${ }^{64}$ Ioana Cismas, 'The Intersection of Economic, Social and Cultural Rights and Civil and Political Rights' in Eibe Riedel, Giles Giacca, Christophe Golay (eds.), Economic, Social and Cultural Rights in International Law: Contemporary Issues and Challenges, (OUP, 2014) 448, 448

${ }^{65}$ Human Rights Council, supra n. 63, 4 para. 7 
${ }^{66}$ See for example Olivier de Schutter, 'The Right of Everyone to Enjoy the Benefits of Scientific Progress and the Right to Food: From Conflict to Complementarity’ (2011) 33(2) Human Rights Quarterly 304; Yvonne Donders, 'The Right to Enjoy the Benefits of Scientific Progress: In Search of State Obligations in Relation to Health’ (2011) 14(4) Medicine, Health Care, and Philosophy 371;

${ }^{67}$ UNGA 'Draft Declarations on Fundamental Human Rights and Freedoms and on Rights and Duties of States' (10 October 1946) UN Doc A/101; UNGA 'Provisional Agenda for the Second Part of the First Session of the General Assembly' (16 October 1946) UN Docs A/118; UN Secretary General 'Preparatory Study Concerning a Draft declaration on the Rights and Duties of States' (1948) UN Doc A/CN.4/2, 20 footnote 94

${ }^{68}$ Commission on Human Rights, 'Analysis of Various Draft International Bills of Rights: Memorandum by the Division of Human Rights’ (23 January 1947) UN Doc E/CN.4/W.16, 1

${ }^{69}$ Ibid. 5

${ }^{70}$ Commission on Human Rights (Drafting Committee) 'Plan of the Draft Outline of an International Bill of Rights' (9 June 1947) UN Doc E/CN.4/AC.1/3/Add.2, p. 4. It is interesting to note that the right has since been subsumed under the banner of cultural rights, although it is clearly a right distinct from cultural rights and more naturally fitting the description of social rights, if not socio-economic rights.

${ }^{71}$ UN Commission on Human Rights UN Doc E/CN.4/SR.70, supra n. 54, 4

${ }^{72}$ UN Commission on Human Rights ( $3^{\text {rd }}$ Session) 'Summary Record of the Seventy-Fourth Meeting' (28 June 1948) UN Doc E/CN.4/SR.74, 3

${ }^{73}$ UNGA (10 ${ }^{\text {th }}$ Session) 'Observations by Governments' (4 October 1955) UN Doc A/2910/Add.5, para 3

${ }^{74}$ UNGA Third Committee UN Doc A/C.3/SR.796, supra n. 56, para 20

${ }^{75}$ Ibid.

${ }^{76}$ UN General Assembly, Universal Declaration of Human Rights, 10 December 1948, 217 A (III), Article 27

77 UN General Assembly, International Covenant on Economic, Social and Cultural Rights, 16 December 1966, United Nations, Treaty Series, vol. 993, p. 3 Art. 15(1)(b)

${ }^{78}$ Ibid. Art. 15(2)

${ }^{79}$ Ibid. Art. 15(3)

${ }^{80}$ Ibid. Art. 15(4)

${ }^{81}$ Commission on Human Rights ( $8^{\text {th }}$ Session) 'Summary Record of the Two Hundred and Ninety-Third Meeting' (27 May 1952) UN Doc E/CN.4/SR.293, 8: See the comments of the delegate from the United Kingdom 'Mr. Hoare pointed out that any text could be interpreted in different ways, despite its author's intention.'

${ }^{82}$ UNGA Third Committee ( $9^{\text {th }}$ Session) $570^{\text {th }}$ Meeting (2 November 1954) UN Doc A/C.3/SR.570, para 3

${ }^{83}$ UNGA (12 ${ }^{\text {th }}$ Session), 'Report of the Third Committee' (5 December 1957) UN Doc A/3764, 22

${ }^{84}$ UNGA Third Committee UN Doc A/C.3/SR.796, supra n. 56, para 4. Regarding definitions, the representative from UNESCO stated at para 5 that a meeting of experts was called to 'analyse the philosophical and legal contents and the principal means of practical application of man's right "freely to participate in the cultural life of the community, to enjoy the arts and to share in scientific advancement and its benefits".'

${ }^{85}$ UNGA Third Committee UN Doc A/C.3/SR.796, supra n. 56, para 4

${ }^{86}$ UNGA Third Committee (12 ${ }^{\text {th }}$ Session) $798^{\text {th }}$ Meeting (1 November 1957) UN Doc A/C.3/SR.798, para 4

${ }^{87}$ Ibid.

${ }^{88}$ UN Commission on Human Rights UN Doc E/CN.4/AC.1/3, supra n. 13, 14 as Article 44

${ }^{89}$ Commission on Human Rights UN Doc E/CN.4/AC.1/SR.15, supra n. 51, 3

90 Ibid.

${ }^{91}$ See UN Commission on Human Rights UN Doc E/CN.4/SR.70, supra n. 54, 4. It is not clear which of Francis Bacon's writing the Chinese Delegate was referring as no explicit is included in the Summary Record of the meeting. However Bacon's work, particularly 'The New Atlantis' and 'The Advancement of Learning', is associated with the advancement of science rather than scientific progress and the Chinese delegate's preference met no opposition when suggested. Isaacs has surmised that, to Bacon, '[s]cientific advancement would be less the outpouring of individual genius than the careful work of many hands; it would be cumulative and progressive.' Leonard N. Isaacs, 'The Effecting of All Things Possible: Molecular Biology and Bacon's Vision' (1987) 30(3) Perspectives in Biology and Medicine 402, 408. This interpretation of Bacon's understanding of scientific advancement very much aligns with the intention of the drafters of the UDHR.

${ }^{92}$ UN Commission on Human Rights, ( $7^{\text {th }}$ Session) 'Suggestions Submitted by the Director-General of the United Nations Educational, Scientific and Cultural Organisations' (27 April 1951) UN Doc E/CN.4/541.Rev.1, 2. The 
text of the longer suggestions reads as follows: "The signatory States undertake to encourage the preservation, development and propagation of science and culture by every appropriate means: (a) by facilitating for all access to manifestations of national and international cultural life, such as books, publications and works of art, and also the enjoyment of the benefits resulting from scientific progress and its application; (b) by preserving and protecting the inheritance of books, works of art and other monuments and objects of historic., scientific and cultural interest; (c) by assuring liberty and security to scholars and artists in their work and seeing that they enjoy material conditions necessary for research and creation; (d) by guaranteeing the free cultural development of racial and linguistic minorities." This article was followed by a separate article, on p. 3, concerning intellectual property rights: "The signatory States undertake to protect by all appropriate means the material and moral interest of every man, resulting from any literary, artistic or scientific works of which he is the author."

${ }^{93}$ Ibid. 3. The text of the alternative shorter proposal reads as follows: "The signatory States undertake to encourage by all appropriate means, the conservation, the development and the diffusion of science and culture. They recognize that it is one of their principal aims to ensure conditions which will permit every one; 1 . to take part in cultural life; 2 . to enjoy the benefits of scientific progress and its applications; 3 « to obtain protection for his moral and material interests resulting from any scientific or artistic production of which he is the author, Each signatory State pledges itself to undertake progressively, with due regard to its organization and resources, and in accordance with the principle of non-discrimination enunciated in paragraph 1, Article 1 of the present Covenant, the measures necessary to attain these objectives in all the territories within its jurisdiction."

${ }^{94}$ UN Commission on Human Rights UN Doc E/CN.4/SR.228, supra n. 57, 10

${ }^{95}$ Commission on Human Rights UN Doc E/CN.4/SR.293, supra n. 82, 6

${ }^{96}$ Ibid.

${ }^{97}$ Ibid.

${ }^{98}$ Ibid. 8

${ }^{99}$ Ibid. 9

${ }^{100}$ Ibid.

${ }^{101}$ UNGA Third Committee (12 ${ }^{\text {th }}$ Session) $799^{\text {th }}$ Meeting (4 November 1957) UN Doc A/C.3/SR.799, para 25

102 Ibid.

${ }^{103}$ Eide, supra n. 1, 296

${ }^{104}$ McGoldrick, supra n. 2, 454

${ }^{105}$ UN Commission on Human Rights UN Doc E/CN.4/SR.228, supra n. 57, 10

106 Ibid. 11

107 Ibid. 12

${ }^{108}$ UN Commission on Human Rights UN Doc E/CN.4/SR.292, supra n. 61, 5

${ }^{109}$ UN Commission on Human Rights ( $8^{\text {th }}$ Session) 'United States of America: Amendment to Article 30' (2 May 1952) UN Doc E/CN.4/L.81

${ }^{110}$ UN Commission on Human Rights UN Doc E/CN.4/SR.292, supra n. 61, 5

${ }^{111}$ UN Commission on Human Rights ( $9^{\text {th }}$ Session) 'Memorandum by the Secretary General' (23 January 1953) UN Doc E/CN.4/673, para 20

112 UN Commission on Human Rights ( $9^{\text {th }}$ Session) 'Memorandum by the Secretary General' (23 January 1953) UN Doc E/CN.4/673, para 20

${ }^{113}$ UN Commission on Human Rights ( $9^{\text {th }}$ Session) 'Memorandum by the Secretary General' (23 January 1953) UN Doc E/CN.4/673, para 20. The wording suggested by the UN Secretary General was as follows: "The States Parties to the Covenant undertake to respect freedom of scientific research and creative activity.",

${ }^{114}$ For example, the delegate from the Philippines felt that using the word indispensable 'gave the impression that the State undertook only to respect a strict minimum of freedom necessary for scientific research and creative activity.' UNGA Third Committee UN Doc A/C.3/SR.796, supra n. 56, para 29

115 Ibid.

116 Ibid.

${ }^{117}$ UNGA UN Doc A/3764, supra n. 84, paras 80 and 82(e)

${ }^{118}$ UNGA Third Committee UN Doc A/C.3/SR.799, supra n. 97, para 18

119 Ibid.

${ }^{120}$ Ibid. 
${ }^{121}$ Ibid. para 32

${ }^{122}$ UNGA UN Doc A/3764, supra n. 84, paras 80 and 82(e)

${ }^{123}$ ICESCR Article 15(4)

${ }^{124}$ UNGA Third Committee (12 ${ }^{\text {th }}$ Session) $795^{\text {th }}$ Meeting (30 October 1957) UN Doc A/C.3/SR.795, 170 para 7

${ }^{125}$ UNGA Third Committee UN Doc A/C.3/SR.796, supra n. 56, para 16

${ }^{126}$ Ibid. para 13

${ }^{127}$ UNGA Third Committee UN Doc A/C.3/SR.795, supra n. 125, 170 para 11

${ }^{128}$ UNGA UN Doc A/3764, supra n. 84, paras 81 and 82(g)

${ }^{129}$ Human Rights Council, 'Report of the Special Rapporteur in the field of cultural rights, Farida Shaheed: The right to enjoy the benefits of scientific progress and its applications' UN Doc A/HRC/20/26 14 May 2012, 3-4. ${ }^{130}$ As Porsdam has observed, associating the right to science too closely with the right to culture, and failing to regard the right to science as an autonomous right, may have 'lessened its value'. See Helle Porsdam, The Transforming Power of Cultural Rights, (CUP, 2009), 134. Porsdam also acknowledges, at 143, that science 'may lead to collective economic, social, and cultural progress.' 